\title{
Enterobiasis pada Anak
}

\author{
Siska Mayasari Lubis, Syahril Pasaribu, Chairuddin P Lubis
}

Departemen Ilmu Kesehatan Anak Fakultas Kedokteran Universitas Sumatera Utara / RSUP H. Adam Malik Medan

Enterobiasis merupakan infeksi yang sering terjadi dalam satu keluarga atau pada orang yang tinggal dalam satu rumah. Infeksi cacing sering diduga pada anak yang menunjukkan rasa gatal di sekitar anus pada waktu malam hari. Anal swab merupakan metode terbaik dalam mendiagnosis enterobiasis. Pemeriksaan periodik disertai dengan pengobatan yang adekuat akan dapat membantu mengurangi kejadian enterobiasis pada anak. Meskipun demikian, masih terdapat kesulitan dalam mengontrol enterobiasis oleh karena mudahnya penularan dan reinfeksi. (Sari Pediatri 2008; 9(5):314-8).

Kata kunci: enterobiasis, anal swab, reinfeksi

$\mathrm{E}$ nterobiasis adalah infeksi parasit yang disebabkan Enterobius vermicularis dan merupakan infeksi yang sering terjadi dalam satu keluarga atau pada orang yang tinggal dalam satu rumah. ${ }^{1,2}$ Enterobius vermicularis juga menjadi penyebab tersering kecacingan pada anak-anak di negara berkembang. ${ }^{3}$ Prevalensi cacing ini tinggi di seluruh dunia, terutama di daerah yang beriklim dingin dan sedang. ${ }^{2,4}$ Infeksi terjadi pada semua usia dengan prevalensi tertinggi pada usia 5-14 tahun dan terutama terjadi di tempat anak tinggal, bermain, dan tidur bersama-sama. ${ }^{5}$

\section{Alamat korespondensi}

Dr. Siska Mayasari Lubis. Bagian Ilmu Kesehatan Anak Fakultas Kedokteran Universitas Sumatera Utara/ RSUP H.Adam Malik Jl. Bunga Lau no.17 Medan. Telepon: (061) 8361721-8365663. Fax. (061) 8361721 E-mail: dr_siskalubis@yahoo.com; kotak Pos 697 Medan20136
Guignard dkk $(2000)^{6}$ menunjukkan angka prevalensi cacing tinggi berkisar $43,4 \%$ dari seluruh populasi anak. Prevalensi tertinggi pada kelompok usia 5-14 tahun 53,4\%. Kim dkk (2002) ${ }^{7}$ melaporkan egg positive rate pada anak sekolah dasar di pulau Geoje, Korea 9,8\%. Chang dkk (1986) ${ }^{8}$ melaporkan kejadian enterobiasis pada anak sekolah dasar di 6 SD di kota Tainan, Taiwan dengan angka infeksi 30,4\%.

Umumnya semua obat cacing dapat digunakan untuk mengobati Enterobiasis. ${ }^{1,9}$ Albendazole mempunyai aktivitas baik in vitro maupun in vivo terhadap berbagai spesisies cacing, terutama terhadap nematoda usus yang menginfeksi manusia. Horton $(1998)^{10}$ melaporkan keberhasilan pengobatan dengan menggunakan Albendazole $400 \mathrm{mg}$ dosis tunggal, dengan cure rate berkisar 97,8\%. Untuk mengontrol penularan enterobiasis, pengobatan yang diberikan sebaiknya dilakukan bersamaan pada seluruh anggota keluarga disertai dengan perbaikan higiene pribadi. ${ }^{11}$ Meskipun demikian, pengobatan pada pasien maupun 
pengobatan satu sekolah sering memberikan hasil yang tidak memuaskan saat dievaluasi kembali. ${ }^{12}$

Konsep reinfeksi dijelaskan pada E.B Cram's summary (1943) berdasarkan masa hidup cacing betina antara 15-28 hari. Cacing muda yang tidak mati oleh obat cacing, akan hidup setelah mengalami proses pertumbuhan selama 18-27 hari. ${ }^{12}$ Hasil anal swab positif kembali dengan cepat seperti pada saat belum mendapat terapi dalam 18-27 hari setelah pemberian single chemotherapy. Fenomena ini diinterpretasikan sebagai keadaan reinfeksi. ${ }^{12}$ Nunez dkk (1996) ${ }^{13}$ melaporkan kejadian reinfeksi yang terjadi dua kali lebih tinggi dari incidence rate (28\%) pada 469 anak setelah diberi pengobatan dengan mebendazole. Dijumpai korelasi antara reinfeksi dan gatal di daerah perianal. Gilman dkk (1991) ${ }^{14}$ melaporkan kejadian reinfeksi yang terjadi pada anak usia $<5$ tahun. Pada awal pemeriksaan didapati $74 \%$ anak terinfeksi, setelah mendapat pengobatan efektif kejadian reinfeksi menjadi 52\%. Meskipun pengobatan yang efektif untuk enterobiasis sudah tersedia selama berabadabad, namun masih terdapat kesulitan dalam mengontrol enterobiasis oleh karena mudahnya penularan dan reinfeksi. ${ }^{15}$

\section{Enterobius vermicularis}

Enterobius vermicularis merupakan cacing yang berukuran kecil berbentuk seperti benang berwarna putih, hidup di sekum, apendiks, dan di daerah yang berbatasan dengan ileum dan kolon asendens. ${ }^{3,4}$ Cacing betina dewasa berukuran $8-13 \mathrm{~mm} \times 0,3-0,5 \mathrm{~mm}$ dengan ekor yang runcing. Bentuk jantan berukuran 2-5 mm x 0,1-0,2 mm, ekornya melingkar sehingga bentuknya seperti tanda tanya. Seekor cacing betina dapat menghasilkan rata-rata 11.000-15.000 butir telur. ${ }^{2,3,16}$

Telur E. vermicularis berbentuk ovoid dengan ukuran 50-60 mm x 20-30 mm, pada salah satu sisinya datar sehingga berbentuk seperti sampan atau bola tangan (American football) (Gambar 1). ${ }^{1,2}$ Dalam suhu badan, telur menjadi infektif dalam 6 jam. Telur dapat kehilangan infektivitasnya setelah 1-2 hari di bawah panas dan keadaan lingkungan yang kering. Kemampuan telur untuk bertahan hidup sangat dipengaruhi oleh temperatur dan kelembaban. ${ }^{17}$ Kemampuan telur untuk bertahan hidup lebih besar pada keadaan dengan temperatur rendah dan

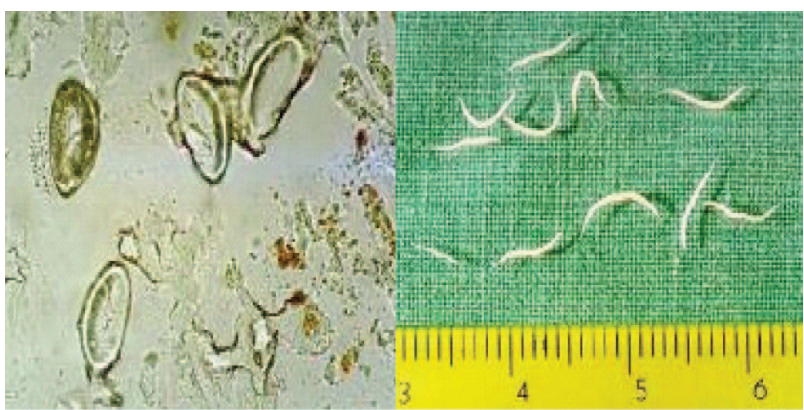

Gambar 1. Telur dan bentuk dewasa E. vermicularis Dikutip dari: Huh S. Pinworm. http://www.emedicine.com/med/topic 1837.htm

kelembaban tinggi. Telur dapat hidup selama $<2$ minggu lamanya kemampuan maksimal telur untuk bertahan hidup dilaporkan sampai 19 minggu. ${ }^{1}$ Desinfektan dan fumigan yang biasa digunakan di rumah tangga tidak dapat membunuh telur. ${ }^{17}$

\section{Penularan}

Manusia terinfeksi bila menelan telur infektif, kemudian menetas di sekum dan berkembang menjadi dewasa. Siklus hidup cacing lebih kurang 1 bulan. ${ }^{2}$ Larva yang dilepaskan dari telur di saluran gastrointestinal akan bermigrasi ke jejenum dan ileum, selanjutnya akan tumbuh menjadi cacing jantan dan betina dewasa. ${ }^{18}$

Setelah membuahi cacing betina, cacing jantan akan mati dan dikeluarkan bersama tinja. Cacing betina yang gravid umumnya pada malam hari akan turun ke bagian bawah kolon dan keluar melalui anus. Telur akan diletakkan di perianal dan di kulit perineum, kadangkadang cacing betina dapat bermigrasi ke vagina. Diperkirakan setelah meletakkan telur, cacing betina kembali ke dalam usus ${ }^{2,3}$ (Gambar 2).

Terdapat 4 cara terjadinya infeksi, yaitu ${ }^{2}$

- Langsung dari anus ke mulut, melalui tangan yang terkontaminasi oleh telur cacing.

- Penularan pada orang yang setempat tidur dengan pasien, infeksi terjadi melalui telur yang ada di alas tempat tidur, sarung bantal, ataupun pada benda yang terkontaminasi.

- Melalui udara, telur cacing yang berada di udara terhirup oleh orang lain (misalnya pada saat membersihkan tempat tidur). 


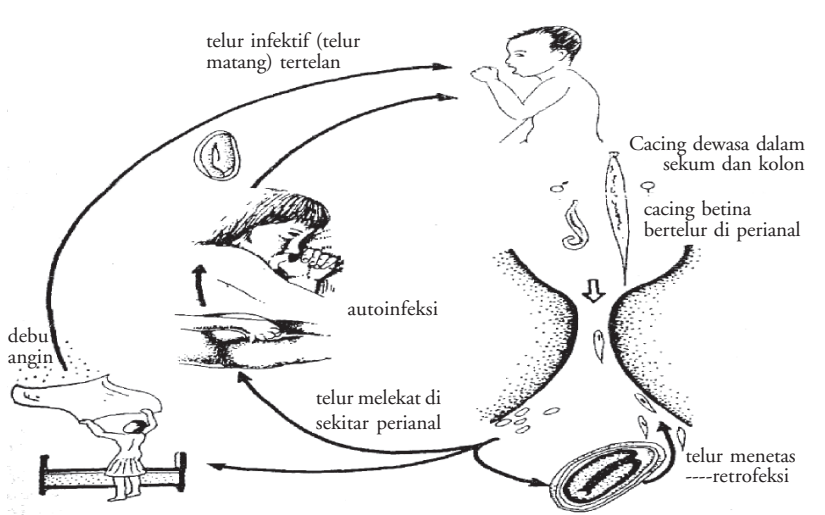

Gambar 2. Daur hidup Enterobius vermicularis

Dikutip dari: Abidin SAN, 1993. ${ }^{16}$

- Retroinfection, pada keadaan yang memungkinkan telur cacing segera menetas di kulit sekitar anus, dan larva yang keluar masuk kembali ke dalam usus melalui anus.

\section{Manifestasi Klinis}

Enterobiasis relatif tidak berbahaya dan infeksi yang terjadi pada umumnya asimtomatik. ${ }^{15,19-21}$ Pada infeksi yang simtomatik, gejala klinis yang mencolok disebabkan iritasi di sekitar anus, perineum, dan vagina oleh cacing betina gravid yang bermigrasi ke daerah anus dan vagina. Hal ini menyebabkan pruritus lokal, anak menggaruk kulit di sekitar anus, berakibat terjadinya iritasi yang bisa diikuti dengan infeksi bakteria sekunder. ${ }^{1-4,16}$ Apabila hal ini tidak segera diatasi, akan gangguan pertumbuhan anak. ${ }^{2}$

Perasaan gatal sering terjadi pada malam hari sehingga pasien terganggu tidurnya, anak menjadi lemah, dan iritabel, (tidur tidak pulas) atau mimpi yang menakutkan (nightmare), sehingga kelopak mata bawah tampak bayangan kulit gelap. ${ }^{2,16}$ Cacing dewasa muda dapat bergerak ke usus halus bagian proksimal sampai ke lambung, esofagus, dan hidung sehingga menyebabkan gangguan di daerah tersebut. Cacing juga sering ditemukan di apendiks tetapi jarang menyebabkan apendisitis. ${ }^{16}$ Cacing betina gravid mengembara dan dapat bersarang di vagina dan tuba fallopii sehingga menyebabkan radang di saluran telur dan vulvovaginitis pada anak perempuan prapubertas. Juga diketahui merupakan penyebab potensial enuresis sekunder dan infeksi saluran kemih. ${ }^{1,16}$ Tidak ada bukti menunjukkan bahwa enterobiasis berhubungan dengan eosinofilia ataupun peningkatan kadar serum imuglobulin E (Ig E). ${ }^{3,20}$

\section{Diagnosis}

Enterobius vermicularis tidak seperti nematoda usus lainnya, telur cacing jarang ditemukan di feses dan hanya dapat mendeteksi telur berkisar 10\%-15\% pasien yang terinfeksi pada pemeriksaan feses rutin. ${ }^{1,5}$ Infeksi cacing sering diduga pada anak yang menunjukkan rasa gatal di sekitar anus pada malam hari. ${ }^{5,16}$ Diagnosis pasti dapat ditegakkan dengan melihat anus si anak pada malam hari dan menemukan cacing dewasa yang sedang keluar untuk bertelur. ${ }^{2}$ Anal swab merupakan metode terbaik dalam mendiagnosis enterobiasis. ${ }^{22,23}$ Telur cacing diambil dengan metode anal swab atau cellophane swab yang ditempelkan di sekitar anus pada pagi hari sebelum anak buang air besar. ${ }^{1,16}$ Infeksi cacing E. vermicularis sering terjadi pada beberapa anggota keluarga, maka sebaiknya seluruh anggota keluarga juga turut diperiksa. ${ }^{19,20}$

Anal swab adalah prosedur pengambilan spesimen dengan mempergunakan alat dari batang gelas atau spatel lidah yang pada ujungnya diletakkan cellophane tape transparan dengan panjang $\pm 6 \mathrm{~cm} \cdot{ }^{16,20}$ Cellophane tape ditempelkan di daerah sekitar anus, maka telur cacing akan menempel pada perekatnya. Kemudian cellophane tape diratakan pada bahan kaca dan dibubuhi sedikit toluol lalu diperiksa di bawah mikroskop, untuk mencari telur cacing $E$. vermicularis. ${ }^{2,16}$ Pemeriksaan ulangan dapat meningkatkan deteksi telur, satu kali pemeriksaan dapat mendeteksi 50\% infeksi, tiga kali pemeriksaan 90\%, dan lima kali pemeriksaan 99\%. ${ }^{4,5}$ Hasil pemeriksaan anal swab yang negatif sebanyak enam kali berturut-turut pada hari yang berbeda dapat menyingkirkan diagnosis. ${ }^{1}$

\section{Pengobatan}

Pengobatan infeksi cacing ini harus dilaksanakan pada seluruh anggota keluarga oleh karena mudah terjadi penularan. ${ }^{1,25,16,20,24}$ Enterobius vermicularis rentan terhadap sejumlah obat cacing, dengan keberhasilan pengobatan $>90 \% .{ }^{1}$ Pirantel pamoate, mebendazole, dan albendazole memiliki efektivitas tinggi dalam mengobati infeksi cacing E. vermicularis. ${ }^{25}$ Albendazole 
diberikan dengan dosis $400 \mathrm{mg}$ per oral, tunggal pada anak $>2$ tahun. Anak yang berumur $<2$ tahun diberikan $100 \mathrm{mg}$. Sedangkan dari mebendazole $100 \mathrm{mg}$ per oral dosis tunggal dan pirantel pamoate dosis $10 \mathrm{mg} / \mathrm{kgBB}$. Keseluruhan obat jika diperlukan dapat diulangi 2-4 minggu kemudian. ${ }^{1,4,25}$

Albendazole adalah obat cacing spektrum luas yang diberikan per oral dan sudah digunakan sejak 1979. ${ }^{26}$ Beberapa bukti menunjukkan bahwa albendazole tidak hanya membunuh cacing dewasa yang hidup di usus tetapi juga membunuh telur dan larva. ${ }^{9}$ Pada pemberian oral albendazole diserap dengan cepat oleh usus. Waktu paruh 8-9 jam, metabolit terutama dikeluarkan lewat urin dan hanya sedikit lewat feses. ${ }^{26}$ Cara kerja albendazole memblokir pengambilan glukosa oleh larva maupun cacing dewasa sehingga persediaan glikogen menurun dan pembentukan ATP berkurang, mengakibatkan kematian parasit (cacing). Untuk penggunaan 1-3 hari terbukti aman. Efek samping berupa nyeri ulu hati, diare, nyeri kepala, mual, lemah, dizziness, insomnia, terjadi pada sekitar 6\% kasus. Pada salah satu penelitian dilaporkan bahwa kejadian efek samping ini sama untuk golongan plasebo dan golongan obat lain. ${ }^{26}$

Mebendazole mempunyai efektivitas tinggi terhadap infeksi nematoda usus dan terutama digunakan untuk mengobati infeksi cacing campuran. Untuk enterobiasis, mebendazole dosis tunggal 100 mg oral cukup efektif, namun albendazole lebih. ${ }^{16}$

Pirantel pamoate merupakan terapi pilihan selain albendazole dan mebendazole, bekerja dengan cara menghambat depolarisasi neuromuskular, menghambat kolinesterase, dan menyebabkan paralisis spastik pada cacing. Untuk kasus enterobiasis sebaiknya pengobatan diulang setelah interval waktu 2 minggu. ${ }^{25}$ Namun, pirantel pamoate yang diberikan dalam dosis tunggal tidak efektif terhadap stadium muda cacing. ${ }^{16}$

\section{Reinfeksi}

Reinfeksi sering terjadi pada kasus enterobiasis setelah mendapat pengobatan. ${ }^{15}$ Sering dilaporkan terjadinya infeksi enterobiasis kembali setelah diberikan pengobatan meskipun dengan dua dosis obat. Reinfeksi terjadi oleh karena telur cacing sulit dibasmi oleh obat cacing sehingga selanjutnya larva akan tumbuh dan berkembang menjadi cacing dewasa. Fenomena ini disebut reinfeksi. ${ }^{18}$ Penting bagi para klinisi untuk melakukan pemeriksaan diagnostik ulangan setelah memberikan terapi untuk mendeteksi kejadian reinfeksi. ${ }^{18}$ Oleh karena itu, dianjurkan untuk memberikan terapi pada seluruh anggota keluarga pada saat yang bersamaan untuk mencegah terjadinya reinfeksi. ${ }^{13,18,25} \mathrm{Kim}$ dkk, $1991^{7}$ melaporkan bahwa skrining masal dan pengobatan efektif untuk mengeradikasi enterobiasis. Sayangnya, eradikasi enterobiasis yang sempurna belum ditemukan sehingga sering terjadi reinfeksi. ${ }^{9}$ Pada keadaan endemik enterobiasis, sulit untuk menetapkan infeksi yang sebenarnya karena sensitivitas perianal swab terbatas dalam mendiagnosis enterobiasis. Oleh karena itu, kasus dengan anal swab negatif seringkali membutuhkan pengobatan. ${ }^{11}$ Sangat sukar untuk mengontrol infeksi di rumah tangga maupun di sekolah oleh karena tingginya angka reinfeksi. ${ }^{20}$ Oleh karena itu, untuk mencegah kejadian reinfeksi pemeriksaan periodik disertai dengan pengobatan yang adekuat akan dapat membantu mengurangi kejadian enterobiasis pada anak. $^{6}$

Penyuluhan mengenai kebersihan pribadi sangat menunjang keberhasilan pengobatan. ${ }^{2}$ Anak yang terinfeksi sebaiknya tidur memakai celana panjang supaya alas kasur tidak terkontaminasi dan tangan tidak dapat menggaruk daerah perianal. Makanan hendaknya dihindarkan dari debu dan tangan yang mengandung parasit. Pakaian dan alas kasur hendaknya dicuci bersih setiap hari. ${ }^{1,2,15,16,19,20} \mathrm{Hal}$ ini merupakan cara yang bermanfaat untuk membatasi penularan telur. ${ }^{19}$

\section{Kesimpulan}

Enterobiasis merupakan penyebab tersering kecacingan pada anak-anak di negara berkembang. Diagnosis pasti adalah dengan melihat anus si anak pada malam hari dan menemukan cacing dewasa yang sedang bertelur atau dengan menggunakan metode anal swab. Hal yang paling penting dalam pengobatan yakni harus dilakukan pada seluruh anggota keluarga pada saat yang bersamaan untuk mencegah terjadinya reinfeksi. Penting bagi para klinisi untuk melakukan pemeriksaan diagnostik ulangan setelah memberikan terapi untuk mengkonfirmasi kejadian reinfeksi. Penyuluhan mengenai kebersihan pribadi sangat berarti dalam menunjang keberhasilan pengobatan. 


\section{Daftar Pustaka}

1. Bundy DAP, Cooper E. Nematodes limited to the intestinal tract (Enterobius vermicularis, Trichuris trichiura, and Capillaria philippinensis). Dalam: Strickland GT, penyunting. Hunter's tropical medicine and emerging infectious disease. Edisi ke-8. Philadelphia: W.B.Saunders Company; 2000. h. 719-21.

2. Lubis CP, Pasaribu S. Oksiuriasis. Dalam: Soedarmo SSP, Garna H, Hadinegoro SRS, penyunting. Buku Ajar Ilmu Kesehatan Anak Infeksi \& Penyakit Tropis. Edisi ke-1. Jakarta: Balai Penerbit FK UI; 2002. h. 423-6.

3. Chaisalee T, Tukaew A, Wiwanitkit V, Suyaphan A, Thiamtip S, Suwansaksri J. Very high prevalence of enterobiasis among the Hilltribal children in rural district "Mae Suk", Thailand. Med Gen Med 2004; 6:132-5.

4. Mahmoud AAF. Intestinal nematodes. Dalam: Mandell GL, Bennett JE, Dolin R, penyunting. Principles and practice of infectious diseases. Edisi ke-5. New York: Churchill Livingstone; 2000. h. 2939-40.

5. Patel SS, Kazura JW. Enterobiasis (Enterobius vermicularis). Dalam: Behrman RE, Kliegman RM, Jenson HB, penyunting. Nelson textbook of pediatrics. Edisi ke-17. Philadelphia: Saunders; 2004. h. 1159-60.

6. Guignard S, Arienti H, Freyre J, Lujan H, Rubinstein H.. Prevalence of enteroparasites in a residence for children in the Cordoba Province, Argentina. Eur J Epid 2000; 16:287-93.

7. Kim JB. Egg positive rate of Enterobius vermicularis of primary school children in Geoje Island. Kor J Par 2003; 41:75-7.

8. Chang JH, Huang WH, Chen ER, Hu SC. Survey of Enterobius vermicularis infection among children in Tainan City. Gaoxiong Yi Xue Ke Xue Za Zhi 1990; 11:587-93.

9. Huh S. Pinworm. Diunduh dari: URL: http://www. emedicine.com/med/topic 1837.htm. Juni 2004.

10. Horton J. Albendazole : A review of anthelmintic efficacy and safety in humans. Parasitology 2000;121:S113-32.

11. Hong ST, Cho SY, Seo BS, Yun CK. Chemotherapeutic control of Enterobius vermicularis infection in orphanages. Kor JPar 1980; 18:37-44.

12. Yang YS, Kim SW, Jung SH, dkk. Chemotherapeutic trial to control enterobiasis in schoolchildren. Kor J Par 1997; 35:265-8.

13. Nunez FA, Hernandez M, Finlay CM. A longitudinal study of enterobiasis in three day care centers of Havana City. Rev Inst Med Trop Sao Paulo 1996; 38:129-32.
14. Gilman RH, Marquis GS, Miranda E. Prevalence and symptoms of Enterobius vermicularis infections in a Peruvian shanty town. Trans R Soc Trop Med Hyg 1991; 85:761-4.

15. Lohiya GS, Figueroa LT. Epidemiology and control of enterobiasis in a developmental center. West J Med 2000; 172:305-8.

16. Abidin SAN. Enterobius vermicularis (Oxyuris vermicularis). Dalam: Gandahusada S, Ilanude HD, Pribadi W, penyunting. Parasitologi kedokteran. Edisi ke-2. Jakarta: Balai Penerbit FK UI; 1993. h. 26-30.

17. The intestinal nematodes of man. Dalam: Belding DL, penyunting. Basic clinical parasitology. New York: Appleton-Century-Crofts, 1958. h. 166-71.

18. Hotez PJ. Helminth infections. Gershon AA, Hotez PJ, Katz SL, penyunting. Krugman's Infectious Diseases of children. Edisi ke-11. Philadelphia: Mosby; 2004. h. 232-3.

19. Steckelberg JM, Wilson WR. Nematodes. Dalam: Wilson WR, penyunting. Current diagnosis \& treatment in infectious diseases. New York: Lange Medical Books/ McGraw-Hill; 2001. h. 856-7.

20. Oberhelman RA. Enterobiasis (pinworm). Dalam: Rudolph CD, Rudolph AM, penyunting. Rudolph's pediatrics. Edisi ke-21. New York: McGraw-Hill; 2003. h. $1105-6$

21. Wolfram W. Enterobiasis. Diunduh dari: URL: http:// www.emedicine.com/ped/topic684.htm. Desember 2003.

22. Celiksoz A, Acioz M, Degerli S, Alim A, Aygan C. Egg positive rate of Enterobius vermicularis and Taenia spp. by cellophane tape method in primary school children in Sivas, Turkey Kor J Par 2005; 43:61-4.

23. Zaman V, Keong LA. Enterobius vermicularis. Dalam: Handbook of medical parasitology. Edisi ke-3. Singapore: Book Editions (S) PTE.LTD; 2000. h. 201-4.

24. Weinberg A, Levin MJ. Infections: paracytic \& mycotic. Dalam: Hay WW, Hayward AR, Levin MJ, Sondheimer JM, penyunting. Current pediatric diagnosis \& treatment. Edisi ke-16. New York: Lange Medical Books/ McGraw-Hill; 2003. h. 1230-1.

25. Tracy JW, Webster LT. Drugs used in the chemotherapy of helminthiasis. Dalam: Goodman \& Gilman's the pharmacological basis of therapeutics. Edisi ke-10. New York: McGraw-Hill; 2001. h. 1122-3.

26. Sukarban S, Santoso SO. Antelmintik. Dalam: Ganiswarna SG, Setiabudy R, Frans DS, Purwantyastuti, Nafrialdi, penyunting. Farmakologi dan terapi. Edisi ke4. Jakarta: Gaya Baru; 1995. h. 533-4. 